\title{
ANALISIS KESALAHAN BERBAHASA PADA PENULISAN CERITA FABEL OLEH SISWA KELAS VIII E DI SMP 2 MUHAMMADIYAH SURAKARTA
}

\author{
Agustina Putri Reistanti \\ SMP Muhammadiyah Al-Kautsar Program Khusus Surakarta \\ Agustina.putrireistanti@yahoo.com
}

\begin{abstract}
This research studies about language errora in writing a fable essay by the students of VIII E at SMP 2 Muhammadiyah Surakarta. This research has four objectives: (1) identifying types of error in a fable essay made by students of VIII E of SMP 2 Muhammadiyah Surakarta; (2) describing the frequency of each error type in a fable essay made by the students of VIII E of SMP 2 Muhammadiyah Surakarta; (3) explaining the most dominant error in writing a fable essay by the students of VIII E of SMP 2 Muhammadiyah Surakarta; and (4) explaining the source of language errors done by the students of VIII E of SMP 2 Muhammadiyah Surakarta. The type of this research is descriptive-qualitative. Data of this research were sentences which contained language errors collected from fable essays written by the students. The research used error analysis as the methodological framework. From this research, it can be seen that language errors done by the students of VIII E of SMP 2 Muhammadiyah Surakarta in writing fable essays were 57 errors. The result showed that there were 3 types of error out of 57 data. Those language errors consist of 33,33\% phonological error; 14,03\% morphological error; and 52,63\% syntactical error. The most dominant type of error is syntactical error which is 30 errors or 52,63\% of error. The researcher also found 2 dominant sources of language error, they were interlingual transfer and intra-lingual transfer.
\end{abstract}

Keywords: error language, fable, types of error

\section{Abstrak}

Penelitian ini mengenai kesalahan berbahasa pada pembuatan karangan cerita fabel oleh siswa kelas VIII E SMP 2 Muhammadiyah Surakarta. Penelitian ini memiliki empat tujuan. (1) Mengidentifikasi tipe-tipe kesalahan pada karangan cerita fabel dibuat oleh siswa kelas VIII E SMP 2 Muhammadiyah Surakarta, (2) Mendeskripsikan frekuensi tipe kesalahan pada karangan cerita fabel dibuat oleh siswa kelas VIII E SMP 2 Muhammadiyah Surakarta, (3) Memaparkan kesalahan yang paling dominan dalam menulis cerita fabel oleh siswa kelas VIII E SMP 2 Muhammadiyah Surakarta, dan (4) Memaparkan sumber kesalahan berbahasa yang dilakukan oleh siswa kelas VIII E SMP 2 Muhammadiyah Surakarta. Jenis penelitian ini bersifat deskriptif kualitatif. Data dalam penelitian ini berupa kalimat yang mengandung kesalahan berbahasa yang dikumpulkan dari karangan cerita fabel yang dibuat oleh siswa. Penelitian ini menggunakan analisis kesalahan sebagai kerangka metodologis. Berdasarkan penelitian terlihat bahwa kesalahan berbahasa yang dilakukan oleh siswa kelas VIII E SMP Muhammadiyah 2 Surakarta dalam pembuatan karangan cerita 
fabel terdapat 57 kesalahan. Hasil penelitian ini penulis menemukan dari 57 data, ada tiga tipe kesalahan. Kesalahan berbahasa tersebut meliputi kesalahan bidang fonologi 33,33\%, kesalahan bidang morfologi 14,03\%, dan kesalahan bidang sintaksis 52,63\%. Tipe kesalahan yang paling dominan adalah kesalahan sintaksis terdapat 30 kesalahan atau 52,63\% dari kesalahan. Peneliti juga menemukan 2 dominan sumber kesalahan berbahasa yaitu transfer interlingual dan transfer intralingual.

Kata Kunci: kesalahan berbahasa, cerita fabel, tipe kesalahan.

\section{Pendahuluan}

Mata pelajaran Bahasa Indonesia diharapkan dapat menciptakan situasi belajar mengajar yang memungkinkan optimal untuk mencapai tujuan keterampilan berbahasa. Ketrampilan berbahasa terdiri atas empat keterampilan yaitu keterampilan menyimak, keterampilan berbicara, keterampilan membaca, dan keterampilan menulis. Berdasarkan ke empat aspek yang dilatihkan siswa, menulis merupakan keterampilan yang harus mendapat perhatian secara sungguh-sungguh. Pengalaman selama ini menunjukkan bahwa kemampuan siswa dalam menulis masih rendah. Padahal kemampuan ini sangat penting. Menulis juga merupakan kemampuan puncak berbahasa seseorang, yang meliputi keterampilan memilih kosa kata, menggunakan struktur kalimat, menerapkan ejaan maupun tanda baca dalam menulis teks cerita.

Menulis merupakan suatu keterampilan berbahasa yang digunakan untuk berkomunikasi secara tidak langsung atau tanpa tatap muka dengan orang lain. Menulis merupakan kegiatan yang produktif dan ekspresif. Keterampilan menulis tidak akan dimiliki seseorang secara otomatis, melainkan harus melalui latihan dan praktik secara terus-menerus. Keterampilan itu juga bukanlah suatu keterampilan yang sederhana, melainkan menuntut sejumlah kemampuan.

Salah satu keterampilan menulis yang dipelajari dalam mata pelajaran Bahasa Indonesia kelas VIII SMP 2 Muhammadiyah Surakarta adalah menulis cerita fabel. Cerita fabel merupakan cerita tentang kehidupan binatang yang berperilaku menyerupai manusia. Fabel termasuk jenis cerita fiksi, bukan kisah tentang kehidupan nyata.

Cerita fabel sering disebut cerita moral karena pesan yang ada di dalam cerita fabel berkaitan erat dengan moral. Tujuan karangan cerita fabel adalah memberi pesan moral bagi pembaca. Oleh karena itu, hendaknya penulis (siswa) mampu menuangkan gagasannya secara sistematis, runtut, dan lengkap. Kenyataannya, masih banyak pula persoalan yang dihadapi siswa dalam membuat karangan cerita fabel. Masalah-masalah yang dihadapi siswa antara lain: (1) sulit menentukan tema dan struktur dari cerita fabel; (2) keterbatasan informasi yang disebabkan kurangnya referensi; (3) adanya rasa malas atau bosan; dan (4) penguasaan kaidah bahasa yang kurang baik.

Contoh kalimat yang ditulis oleh siswa "Burung pleci Dan Kenari Di tempatku akan mengadakan lomba. Kalimat tersebut seharusnya "Burung pleci dan kenari akan mengadakan lomba di tempatku”. Pada kalimat tersebut terlihat ada kesalahan berbahasa dalam bidang fonologi yaitu kesalahan penulisan huruf kapital yang digunakan di tengah kalimat yaitu kata dan yang menunjukkan kata hubung dan preposisi di- yang seharusnya penulisannya menggunakan huruf kecil.

Melihat salah satu contoh kesalahan di atas banyaknya aspek kesalahan berbahasa yang dapat diteliti dalam penulisan cerita fabel oleh siswa. Kegiatan analisis kesalahan mengenai kesulitan tata bahasa dalam mengarang. Berdasarkan contoh di atas siswa kesulitan dalam 
bidang ejaan, diksi, dan kalimat. Kesalahan berbahasa yang dibuat siswa merupakan suatu bagian belajar yang tidak terhindarkan. Oleh karena itu, mini project ini akan membahas (1) tipe-tipe kesalahan yang dibuat oleh siswa, (2) frekuensi tipe kesalahan, (3) kesalahan yang paling dominan dalam menulis cerita fabel, dan (4) sumber kesalahan berbahasa yang dilakukan oleh siswa.

\section{Metode Penelitian}

Penelitian ini merupakan penelitian kualitatif deskriptif karena penulis bertujuan untuk mendeskripsikan kesalahan bahasa pada penulisan cerita fabel yang dibuat oleh siswa kelas VIII SMP 2 Muhammadiyah Surakarta. Berdasarkan penulisan cerita fabel dapat diidentifikasikan kesalahan bahasa, di antaranya tipe-tipe kesalahan yang dibuat oleh siswa, mengidentifikasi frekuensi dari tipe-tipe kesalahan, menjelaskan kesalahan yang paling dominan, dan mengidentifikasi sumber kesalahan. Subjek penelitian ini adalah siswa kelas VIII E SMP 2 Muhammadiyah Surakarta. Objek penelitian yang digunakan dalam penelitian adalah kesalahan kebahasaaan pada penulisan cerita fabel yang dibuat oleh siswa kelas VIII SMP Muhammadiyah Surakarta.

Data berupa kalimat yang mengandung kesalahan berbahasa yang dikumpulkan dari karangan cerita fabel yang dibuat oleh siswa. Ada 5 karangan cerita fabel yang dibuat oleh siswa kelas VIII SMP 2 Muhammadiyah Surakarta. Metode analisis data yang digunakan dalam penelitian ini adalah metode padan. Metode padan adalah metode analisis bahasa dengan menggunakan alat penentu diluar bahasa dan tidak menjadi bagian bahasa yang bersangkutan (Sudaryanto, 1993, p.3). Metode padan dengan teknik padan referensial digunakan untuk mengidentifikasi dan menganalisis bidang kesalahan berbahasa. Metode analisis kesalahan berbahasa memiliki prosedur. Adapun prosedur (algoritma) analisis kesalahan berbahasa pertama kali didesain oleh Corder (dalam Fauziati, 2009, p.136-137) prinsipnya terdiri dari tiga tahapan utama, yaitu: pengenalan, pendeskripsian, dan eksplanasi kesalahan. Tahapan ini kemudian oleh Sridhar (1980, p.103) dan selanjutnya oleh James (dalam Fauziati,2009, p.136-137) prosedur analisis kesalahan berbahasa yaitu.

a. Mengumpulkan data kesalahan berupa kalimat dan paragraf dari penyusunan struktur teks cerita fabel.

b. Mengidentifikasi kesalahan pada teks cerita fabel yang dibuat oleh siswa kelas VIII.

c. Mengklasifikasikan ke dalam tipe kesalahan.

d. Mengurutkan kesalahan berdasarkan frekuensinya, kesalahan itu dilihat dan diurutkan berdasarkan tingkat keseringan terjadinya kesalahan dengan menggunakan rumus:

Presentasi kesalahan :

Jumlah kesalahan x $100 \%$

\section{Jumlah keseluruhan kesalahan}

e. Menjelaskan kesalahan yang dilakukan berdasarkan penyebab terjadinya kesalahan.

f. Terapi atau remidi (melalui pengajaran)

g. Menganalisis sumber kesalahan.

h. Menetukan tingkat keseriusan kesalahan dan mendesain remedi (pemulihan)

\section{Hasil dan Pembahasan}

\subsection{Tipe-Tipe Kesalahan}

Berdasarkan cerita fabel yang ditulis oleh siswa kelas VIII SMP 2 Muhammadiyah Surakarta, maka ditemukan data kesalahan berbahasa. 


\subsubsection{Kesalahan berbahasa bidang fonologi}

Kesalahan bidang fonologi yang dilakukan oleh siswa kebanyakan pada kesalahan penggunaan huruf. Berikut data yang menunjukkan penggunaan kesalahan berbahasa siswa.

a. Kesalahan penggunaan huruf kapital

Berikut data yang ditemukan mengandung kesalahan penggunaan huruf kapital. Kaidah penggunaan huruf kapital adalah huruf kapital digunakan di awal kalimat.

1) dia terus terus mencoba keluar dari kulit telurnya. (bentuk salah)

(1a) Dia terus terus mencoba keluar dari kulit telurnya. (bentuk benar)

2) ternyata, binatang itu tidak bersahabat. (bentuk salah)

(2a) Ternyata, binatang itu tidak bersahabat. (bentuk benar)

3) ayam betina selalu mengengkramimu sampai kamu menetas dan kamu bisa berjalan. (bentuk salah)

(3a) Ayam betina selalu mengengkramimu sampai kamu menetas dan kamu bisa berjalan. (bentuk benar)

4) saat salah satu ayam menapakan kakinya ke jembatan itu ayam lainnya pun tudak mau mengalah. (bentuk salah)

(4a) Saat salah satu ayam menapakan kakinya ke jembatan itu ayam lainnya pun tudak mau mengalah. (bentuk benar)

5) kalian semua pasti juga mengagumi ketampanan ku ini. (bentuk salah)

(5a) Kalian semua pasti juga mengagumi ketampanan ku ini. (bentuk benar)

6) ular itu ingin memakan Ayam itu. (bentuk salah)

(6a) Ular itu ingin memakan Ayam itu. (bentuk benar)

7) ia selalu mengingat kebaikan teman-temannya yang telah menyelamatkannya. (bentuk benar)

(7a) Ia selalu mengingat kebaikan teman-temannya yang telah menyelamatkannya. (bentuk salah)

8) masing-masing tiba di tepi jurang yang di bawahnya mengalir air sungai yang sangat deras. (bentuk salah)

(8a) Masing-masing tiba di tepi jurang yang di bawahnya mengalir air sungai yang sangat deras. (bentuk benar)

Kesalahan terlihat pada kalimat (1) sampai dengan kalimat (8) yaitu pada kata dia, ternyata, ayam, saat, kalian, ular, ia, dan masing-masing. Kesalahan yang dilakukan oleh siswa adalah penggunaan huruf kecil pada awal kalimat. Seharusnya huruf kapital digunakan pada awal kalimat. Jadi, pembetulan terlihat pada kalimat (1a) sampai dengan (8a) yaitu Dia, Ternyata, Ayam, Saat, Kalian, Ular, dan Ia, dan Masing-masing. Penggunaan huruf kapital di bawah ini yang ditunjukkan pada kalimat (9) sampai dengan kalimat (15) merupakan bentuk kesalahan penggunaan huruf kapital. Kesalahan penulisan huruf capital yang diletakkan di tengah kalimat. Misalnya pada kata Pada Suatu, Seekor Ayam, Sedang, Aku, Pergi, Setelah, Ayam, Jalan, Pohon, dan Jatuh.

9) Dikisahkan Pada Suatu hari ada Seekor Ayam yang Sedang keluar dari telurnya.

10) Agar $A k u$ memperbanyak daging ku tunggu 4-5 minggu lagi.

11) ...kemudian ular itu Pergi dan mencari mangsa yang lain.

12) ...tapi Setelah dicari-cari Ayam itu pun tidak ketemu.

13) ...kata si bebek sambil berjalan-Jalan. 
14) ...tanpa sengaja ia menabrak ranting Pohon yang tinggi sayapnya patah.

15) ...sebuah pohon yang Jatuh telah dijadikan jembatan untuk menyebrang jurang tersebut.

Bentuk pembetulan penggunaan huruf kapital pada nomor 9-15 ditunjukkan pada kalimat di bawah ini.

(9a) Dikisahkan pada suatu hari ada seekor ayam yang sedang keluar dari telurnya.

(10a) Agar aku memperbanyak daging ku tunggu 4-5 minggu lagi.

(11a) ....,kemudian ular itu pergi dan mencari mangsa yang lain.

(12a) tapi Setelah dicari-cari Ayam itu pun tidak ketemu.

(13a) kata si bebek sambil berjalan-jalan.

(14a) ...tanpa sengaja ia menabrak ranting pohon yang tinggi sayapnya patah.

(15a) ... sebuah pohon yang jatuh telah dijadikan jembatan untuk menyebrang jurang tersebut.

b. Kesalahan penulisan klitik

Klitik merupakan penggalan kata ganti, namun penulisannya tidak dapat dipisah dengan kata yang mendampinginya. Kalimat (1) sampai dengan kalimat (2) di bawah ini menunjukkan kesalahan penulisan klitik.

1) Agar aku memperbanyak daging $k u$ tunggu 4-5 minggu lagi

(1a) Agar aku memperbanyak dagingku tunggu 4-5 minggu lagi.

Penulisan kata daging $k u$ pada kalimat (1) seharusnya penulisannya dirangkai dengan kata yang mendahuluinya. Jadi, pembetulan kalimat (1) ditunjukkan dengan kalimat (1a).

2) Kalian semua pasti juga mengagumi ketampanan $k u$ ini.

Kalimat (2) menunjukkan kesalahan penggunaan klitik karena kata ketampanan ku seharusnya penggalan kata ganti dirangkai dengan kata yang mendahuluinya. Jadi, pembetulan kalimat (2) terlihat pada kalimat (2a) berikut.

(2a) Kalian semua pasti juga mengagumi ketampananku ini.

c. Kesalahan penulisan partikel

Kesalahan penulisan partikel -pun kebanyakan terjadi karena penulis merangkai partikel yang seharusnya ditulis terpisah. Kesalahan kalimat (1) menunjukkan penggunaan partikel - pun yang penulisannya dirangkai. Bentuk penulisan yang benar ditunjukkan kalimat (1a) yang sesuai kaidah penggunaan partikel -pun penulisannya terpisah dengan kata yang mendahuluinya. Berikut data yang menunjukkan kesalahan penggunaan partikel.

1) Diapun menang bersama.

(1a) Dia pun menang bersama.

d. Kesalahan penulisan penggabungan kata

Kata ditulis sebagai satu kesatuan yang berdiri sendiri. Imbuhan (awalan, sisipan, atau akhiran) pada kata tuturan dituliskan serangkai dengan kata dasarnya. Gabungan kata yang hanya mendapat awalan atau akhiran ditulis serangkai dengan kata yang bersangkutan saja/ kata yang dekat dengannya, kata lainnya tetap ditulis terpisah dan 
tidak diberi tanda hubung. Kalimat (1) terlihat kata berterimakasih pennulisannya salah, karena kata majemauk tersebut hanya mendapatkan awalan saja. Apabila kata majemuk mendapatkan awalan maka, penulisannya harus dirangkai dengan kata yang berdekatan dengan awalannya saja dan kata lainya tetap ditulis terpisah.

1) Si bebek lalu tersenyum dan berterimakasih kepada si ayam. (bentuk salah)

(1a) Si bebek lalu tersenyum dan berterima kasih kepada si ayam. (bentuk benar)

Kalimat (1a) menunjukkan pembetulan dari kalimat (1). Penulisan kata majemuk berterima kasih memang seharusnya dipisah karena mendapatkan awalan saja. Jika mendapatkan awalan dan akhiran penulisannya dirangkai semua.

\subsubsection{Kesalahan Bidang Morfologi}

Kesalahan bidang morfologi adalah kesalahan yang berhubungan dengan tata bentuk kata. Kesalahan yang sering dilakukan oleh siswa adalah kesalahan penulisan kata depan, kesalahan karena pleonasme. Berikut data yang menunjukkan kesalahan pada bidang morfologi.

a. Kesalahan imbuhan ber-

Kata-kata yang seharusnya berprefiks ber- sering diberi prefiks ke-. Misalnya pada kalimat (1) kata ketemu seharusnya kata yang benar adalah bertemu pada kalimat (1a). Hal itu dilakukan karena kekurangcermatan dalam memilih awalan yang tepat. Pada umumnya kesalahan itu terjadi karena pemakai bahasa terpengaruh oleh struktur bahasa daerah. Kata yang bercetak miring di bawah ini menunjukkan kekurangcermaran dalam memilih awalan yang tepat.

1) Ayam itu pun tidak ketemu ibunya. (Salah)

(1a) Ayam itu pun tidak bertemu ibunya. (Benar)

b. Kesalahan pemakaian sufiks - nya

Kata di bawahnya pada kalimat (1) digunakan untuk bahasa lisan atau bahasa yang tidak resmi. Kata seperti itu merupakan pengaruh dari bahasa daerah (Jawa). Dalam bahasa yang baku kita harus menggunakan kata dibawah tanpa sufiks -nya. Berikut kalimat (1) yang menunjukkan pemakaian sufiks - nya yang kurang tepat.

1) Masing-masing tiba di tepi jurang yang di bawahnya

(1a) Masing-masing tiba di tepi jurang yang di bawah.

Berdasarkan pembetulan pada kalimat (1a) kata di bawah memiliki bentuk yang lebih baku daripada kata dibawahnya pada kalimat (1).

c. Kesalahan penulisan kata depan

Penulisan kata di, ke, dan dari seharusnya terpisah dari kata yang mengikutinya. Berikut kalimat (1) sampai dengan kalimat (4) merupakan bentuk kesalahan pemakaian kata depan yang penulisannya dirangkai.

1) Elang itu kini terbang melayang diatasnya.

2) Ibumu bertelur dikandang ayam.

3) Seekor bebek yang sedang berjalan-jalan disamping.

4) Akhirnya ular itu menuju kekandang 
Pembetulan dari kalimat di atas sebagai berikut.

(1a) Elang itu kini terbang melayang di atasnya.

(2a) Ibumu bertelur di kandang ayam.

(3a) Seekor bebek yang sedang berjalan-jalan di samping.

(4a) Akhirnya ular itu menuju ke kandang

d. Kesalahan karena pleonasme

Pleonasme dapat disebabkan oleh ketidaksengajaan penulis atau pembicara dalam menyampaikan kalimat dan makna yang berlebihan. Pleonasme adalah pemakaian kata mubazir yang sebenarnya tidak perlu untuk penegas arti maupun hanya sebagai gaya. Jika dihilangkan salah satu unsurnya, maknanya tetap utuh. Berikut contoh kalimat yang mengandung kesalahan karena pleonasme ditunjukkan kalimat (1) dan kalimat (2).

1) Elang itu kini terbang melayang di atas.(bentuk salah)

(1a) Elang itu kini terbang melayang. (bentuk benar)

Bentuk kesalahan kalimat (1) merupakan kesalahan bentuk pada frase melayang di atas. Penggunan frasa tersebut menjadi berlebihan karena kata melayang digabung dengan di atas yang sebenarnya memiliki arti yang sama karena melayang pasti ke atas. Pembetulan kalimat (1a) merupakan bebtuk efektif dari kalimat (1) dengan menghilangkan kata di atas.

2) Si kelinci apalagi sangat lebih marah kepada kucing. (bentuk salah)

(2a) Si kelinci apalagi lebih marah kepada kucing. (bentuk benar)

Bentuk kesalahan kalimat (2) merupakan bentuk kesalahan karena bentuk superlatif. Bentuk superlatif yang berlebihan terdapat pada frasa sangat lebih marah. Kalimat (2a) menunjukkan kalimat benar cukup menggunakan frasa lebih marah. Penghilangan kata sangat pada kalimat (2) bertujuan untuk menghemat kalimat.

\subsubsection{Kesalahan Berbahasa dalam Bidang Sintaksis}

Kesalahan sintaksis adalah kesalahan atau penyimpangan struktur frasa, klausa, atau kalimat, serta ketidaktepatan pemakaian partikel. Analisis kesalahan dalam bidang tata kalimat menyangkut urutan kata, kepaduan, susunan frasa, kepaduan kalimat, dan logika kalimat.

a. Kalimat berstruktur tidak baku merupakan suatu kalimat yang susunannya tidak sesuai dengan kaidah bahasa Indonesia yang ditentukan. Kalimat berstruktur tidak baku ditemukan pada data di bawah ini. Contoh kalimat berstruktur tidak baku pada karangan siswa.

1) Burung itu menggoda kucing dan kelinci untuk bermusuhan. (bentuk salah)

(1a) Burung itu menggoda kucing dan kelinci agar saling bermusuhan. (bentuk benar)

Kesalahan yang kurang tepat dalam penyusunan kalimat sehingga menyebabkan kalimat (1) memiliki makna yang kurang jelas. Pada kalimat (1) terdapat kata untuk yang memberikan makna kurang jelas. Kalimat tidak baku strukturnya karena kata aspek untuk disisipkan di antara pelaku dan pokok kata kerja.

2) Dan pada keesokkan harinya ia menemui burung beo yang usil. (bentuk salah)

(2a) Keesokan hari, ia menemui burung beo yang suka mengganggu. (bentuk benar) 
3) Dan akhirnya dia sudah tau penyebabnya adalah seekor burung beo itu dan dia menghukum burung beo. (bentuk salah)

(3a) Akhirnya dia sudah tahu penyebabnya karena seekor burung beo dan dia menghukum burung beo. (bentuk benar)

Bentuk struktur tidak baku kalimat (2) dan kalimat (3) ditunjukkan pada penggunaan kata hubung dan di awal kalimat. Penggunaan kata hubung dan digunakan untuk menghubungkan antara dua kalimat yang merupakan kalimat majemuk.

4) Si bebek itu berfikir,"Kenapa saudaraku tidak mau kalau aku bersama saudaraku, apa aku jelek?

(4a) Si bebek itu berpikir, "Mengapa saudaraku tidak mau kalau aku bersamanya, apa aku jelek?"

Bentuk struktur tidak baku kalimat (4) yaitu penggunaan kata berfikir dan kenapa. Kedua kata itu menyebabkan kalimat menjadi tidak baku. Seharusnya kata berfikir dan kenapa diganti menggunakan kata berpikir dan mengapa yang tampak pada kalimat (4a).

5) Si bebek kangen dan sabar lalu si bebek pulang dengan hati sedih.

(5a) Si bebek rindu dan sabar menunggu, lalu si bebek pulang dengan hati bersedih.

Bentuk struktur yang tidak baku kalimat (5) terlihat pada penggunaan kata kangen merupakan kata tidak baku dari rindu, sedangkan ada kalimat yang kurang lengkap sehingga membuat kalimat itu maknanya kurang jelas.

6) Dia cuman memiliki 2 minggu untuk berkembangbiak.

(6a) Dia hanya memiliki 2 minggu untuk berkembangbiak.

Kesalahan struktur tidak baku karena penggunaan kata cuman pada kalimat (6). Kata cuman digantikan dengan kata hanya yang memiliki bentuk baku baku.

7) Pohon yang dijadikan jembatan tersebut sangatlah kecil sehingga tidak dapat dilalui secara bersamaan oleh dua ekor ayam yang kecil dengan slamat, apalagi oleh dua ekor ayam.

(7a) Pohon yang dijadikan jembatan sangat kecil sehingga tidak bisa dilalui oleh dua ekor ayam secara bersamaan dengan selamat.

Bentuk struktur baku terlihat pada kalimat (7a) di atas, kalimat (7) merupakan bentuk yang tidak baku. Kalimat (7) memiliki struktur yang terbolak-balik sehingga makna kurang jelas. Pada kalimat (7) kalimat dua ekor ayam yang kecil dan selamat menyebabkan kalimat tersebut sulit dipahami.

8) Ayam lainnya pun tidak mau mengalah dan malahan saling berantem dengan jalunya yang panjang.

(8a) Ayam yang lain tidak mau mengalah dan saling bertengkar dengan jalunya.

Kata malahan dan berantem merupakan penyebab struktruk tidak baku pada kalimat (8) karena terpengaruh oleh struktur bahasa Jawa, sedangkan kata berantem seharusnya diganti dengan kata bertengkar yang memiliki bentuk yang lebih baku. 
b. Kalimat ambigu

Kalimat ambigu merupakan kalimt yang memiliki makna ganda, karena bermakna ganda kalimat itu dapat membingungkan orang yang membacanya atau orang yang mendengarnya. Penyebab ambiguitas kalimat pada umumnya adanya keterangan atau atribut yang lebih dari satu. Berikut data yang menunjukkan kalimat ambigu.

1) Dan pada keesokan harinya mereka sudah berkumpul di arena yang arena tidak jauh. (bentuk salah)

(1a) Keesokkan harinya mereka sudah berkumpul tidak jauh dari arena. (bentuk benar)

2) Pada suatu hari Deo terbang sendirian mengelilingi hutan. Tanpa sengaja ia menabrak ranting pohon yang tinggi sayapnya patah.(bentuk salah)

(2a) Suatu hari Deo terbang sendiri mengelilingi hutan dan tanpa sengaja ia menabrak ranting pohon dan sayapnya patah. (bentuk benar)

3) Setelah itu ayamnya pergi dari kandang ayam berganti kadang yang baru. (bentuk salah)

(3a) Setelah itu ayam pergi dan berganti ke kandang yang baru. (bentuk benar)

c. Kalimat yang tidak jelas

Kalimat tidak jelas adalah kalimat yang kandungan maknanya tidak jelas. Ketidakjelasan itu sereng kali berkaitan dengan gabungan antara pilihan kata yang kurang tepat dan struktur tidak baku. Ketidakjelasan kalimat bisa disebabkan oleh kata-kata yang bertentangan maknanya. Berikut kalimat yang menunjukkan ketidakjelasan makna.

1) Pada suatu hari ada si kucing yang sedang berjalan mengelilingi hutan dengan gembira dan ia menemui kelinci yang sangat gembira.

(1a) Suatu hari si kucing mengelilingi hutan, tiba-tiba bertemu dengan kelinci sehingga si kucing sangat gembira.

Kalimat (1) kurang jelas maknanya karena ada unsur yang kurang jelas, maka kalimat (1) harus ditambah konjungsi sehingga supaya maknanya jelas.

2) Kelinci dan kucing dalam hitungan " $3,2,1$ " mereka pun berlari saling bersaing kebolehan dan dia pun menang bersama. (bentuk salah)

(2a) Kelinci dan kucing bersaing lomba lari, dalam hitungan " $3,2,1$ " mereka mulai berlari, dan akhirnya keduanya jadi pemenang. (bentuk benar)

3) Dan akhirnya dia sudah tau penyebabnya adalah seekor burung beo itu.

(3a) Akhirnya dia sudah tahu penyebabnya karena burung beo.

4) Tetapi kedua ayam tersebut tidak merasa ketakutan. Rasa sombong dan harga diri mereka tidak membiarkan jalan terlebih dahulu kepada ayam lainnya.

(4a) Kedua ayam itu tidak merasa ketakutan karena memiliki rasa sombong dan harga diri, sehingga mereka tidak membiarkan ayam lain jalan mendahuluinya.

d. Diksi yang tidak tepat dalam membentuk kalimat

Diksi merupakan pilihan kata. Diksi adalah pilihan kata dan kejelasan lafal untuk menggambarkan efek tertentu dalam berbicara di depan umun atau dalam karangmengarang. Ketidaktepatan pemilihan kata yang digunakan dalam kalimat menyebabkan makna kalimat yang tidak jelas. Berikut kalimat (1) sampai dengan kalimat(10) merupakan data yang menggunakan diksi yang kurang tepat. Kata yang bercetak miring di bawah ini merupakan pemilihan diksi yang kurang tepat.

1) Dan dia menghukum burung beo dan si kucing dan si kelinci bersahabat hingga tua. (bentuk salah) 
1a) Dia menghukum burung beo. Pada akhirnya si kucing dan si kelinci bersahabat sampai tua. (bentuk benar)

Penggunaan diksi yang tidak tepat pada kalimat (1) terdapat pada konjungsi dan di awal kalimat yang seharusnya konjungsi dan digunakan untuk menghubungkan antar kalimat. Penggunaan konjungsi dan digunakan dua kali di tengah kalimat mengakibatkan makna kalimat kurang jelas.

2) Deo mendengar suara elang di kejahuan. (bentuk salah)

(2a) Deo mendengar suara elang dari kejahauan. (bentuk benar)

Pemilihan kata depan di yang krang tepat pada kalimat (2) sehingga mnyebabkan kalimat kurang jelas maknanya. Kata depan $d i$ - menunjukkan tempat, sedangkan pemilihan kata depan dari berdasarkan konteks kalimat (2a) menunjukkan jarak.

3) Jantungnya berdegup kencang. (bentuk salah)

(3a) Jantungnya berdetak kencang. (bentuk benar)

Penggunaan kata berdegub pada kalimat (3) kurang sesuai. Kata yang sesuai adalah berdetak. Jantung tidak bedegub tetapi berdetak.

4) Deo yang masih tergletak di tanah merasa terharu. (bentuk salah)

(4a) Deo yang masih terbaring di tanah merasa terharu. (bentuk benar)

Penggunaan kata tergletak pada kalimat (4) kurang sesuai. Kata yang sesuai adalah berdetak. Penggunaan kata tergletak masih terpengaruh bahasa daerah (Jawa). Kata geletak merupakan bahasa Jawa, sehingga kata tergletak digantikan dengan kata terbaring.

5) Karena aku baru keluar dari telur dan dagingku sedikit. Aku minta agar aku memperbanyak dagingku. (bentuk salah)

(5a) Aku baru keluar dari telur, dagingku pun masih sedikit. Biarkanlah aku memperbanyak dagingku dahulu. (bentuk benar)

6) Tapi setelah dicari-cari ayam itu pun tidak ketemu karena waktu ayam lahir dia cuman memiliki 2 minggu untuk berkembangbiak. (bentuk salah)

(6a) Setelah dicari ayam itupun tidak ketemu. Waktu ayam itu lahir hanya membutuhkan waktu 2 minggu untuk berkembangbiak. (bentuk benar)

7) Jembatan yang sangat kecil itu akan menjadi ketakutan.(bentuk salah)

(7a) Jembatan yang sangat kecil itu akan menjadi petaka.(bentuk benar)

Pemakaian kata ketakutan kalimat (7) kurang tepat, yang tepat adalah petaka. Kata petaka lebih tepat digunakan karena petaka menimbulkan bencana.

8) Dua ekor ayam berjalan dengan tegasnya dari arah yang berlawanan di sebuah pegunungan yang curam. (bentuk salah)

(8a) Dua ekor ayam berjalan dengan cepat dari arah berlawanan dari sebuah pegunungan yang curam. (bentuk salah)

9) Saat salah satu ayam menampakkan kakinya ke jembatan itu, ayam lainnya pun tidak mau mengalah dan malahan saling berantem dengan jalunya yang panjang.

(9a) Ketika salah satu ayam menginjakkan kaki ke jembatan, ayam lainnya tidak mau mengalah untuk bisa menyebrangi jembatan. Akhirnya ayam-ayam itupun saling bertengkar dengan jalunya.

Penggunaan kata saat, menampakkan, dan berantem pada kalimat (9) merupakan bentuk yang kurang tepat. Kata tersebut bisa digantikan dengan kata ketika, menginjak, 
dan bertengkar. Ketiga kata tersebut mengakibatkan kalimat tidak jelas maknanya. Menampakkan artinya dapat dilihat, sedangkan menginjakkan artinya meletakkan kaki pada suatu tempat.

10) Sehingga kedua ayam tersebut akhirnya jatuh ke dalam jurang dan tersapu oleh aliran air.

10a) Akhirnya kedua ayam tersebut jatuh ke jurang dan terbawa oleh aliran air.

Kata sehingga seharusnya tidak di awal kalimat, karena kata sehingga merupakan konjungsi yang menyatakan akibat. Kata sehingga mengakibatkan makna dalam kalimat kurang jelas. Jadi, kata sehingga digantikan dengan kata akhirnya yang lebih padu. Selanjutnya, kata tersapu digantikan dengan kata terbawa. Kata tersapu memiliki arti sudah di sapu atau dibersihkan, sedangkan kata terbawa memiliki arti terseret. Jadi, kata yang tepat untuk menggantikan kata tersapu pada kalimat (10) adalah terbawa.

e. Penggunaan kata mubazir

Kalimat yang mengandung kata mubazir adalah kalimat yang berlebihan-lebihan sehingga mengakibatkan tidak hemat, sia-sia, dan tidak berguna. Berikut contoh data yang ditunjukkan kalimat (1) sampai (5) yang menunjukkan kata mubazir. Kaa mubazir ditunjukkan dengan kata yang bercetak miring pada kalimat (1) sampai (5).

1) Kelinci dan kucing dalam hitungan " $3,2,1$ " mereka pun berlari saling bersaing kebolehan dan dia pun menang bersama. (bentuk salah)

(1a) Kelinci dan kucing akan lomba berlari adu kebolehan. Mereka mulai berlari dalam hitungan "3,2,1", dan akhirnya keduanya jadi pemenang. (bentuk benar)

2) Ternyata kawanan burung itu teman-temannya sendiri yang selama ini tidak dipedulikan. (bentuk salah)

(2a) Ternyata kawanan burung itu temannya sendiri yang selama ini tidak dipedulikan. (bentuk benar)

3) Dikisahkan pada suatu hari yang cerah ada seekor bebek yang sedang berjalanjalan disamping rumah saya. (bentul salah)

(3a) Suatu hari yang cerah ada seekor bebek yang sedang berjalan di samping rumah saya. (bentuk benar)

4) Saat itu secara kebetulan mereka secara bersamaan masing-masing tiba di tepi jurang yang dibawahnya mengalir air sungai yang sangat deras. (bentuk salah)

(4a) Saat itu mereka secara kebetulan bersamaan tiba di tepi jurang dan di bawahnya mengalir air yang sangat deras. (bentuk benar)

5) Akhirnya ular itu menuju ke kandang Ayam, tapi setelah dicari-cari Ayam itu pun tidak ketemu. (bentuk salah)

(5a) Akhirnya ular itu menuju ke kandang Ayam, tapi setelah dicari Ayam itu pun tidak ketemu. (bentuk benar)

Bentuk kesalahan kalimat (5) merupakan kesalahan bentuk jamak pada kata di cari. Kata cari mengandung arti jamak. Kata yang sudah jamak menjadi sia-sia. Kalimat (5) cukup menggunakan kata kerja dicari sudah menjelaskan makna melakukan suatu pekerjaan. Pembetulan kalimat (5) terlihat pada kalimat (5a) di atas.

Berdasarkan analisis data yang dilakukan oleh peneliti terhadap karangan cerita fabel yang dibuat oleh siswa kelas VIII E SMP Muhammadiyah 2 Surakarta terdapat tiga tipe kesalahan, yaitu kesalahan fonologi, morfologi, dan sintaksis. 


\subsubsection{Frekuensi Tipe Kesalahan}

Berdasarkan klasifikasi kesalahan di atas telah diperoleh paparan lengkap tipe-tipe kesalahan berdasarkan kategori linguistik. Secara keseluruhan terdapat 57 data kesalahan yang berhasil dikumpulkan dari seluruh sumber data. Hasil analisis menunjukkan ada beberapa kesalahan-kesalahan linguistik. Adapun frekuensi kesalahan yang ditemukan dalam data dapat dilihat pada tabel di bawah ini.

Tabel Frekuensi Tipe Kesalahan

\begin{tabular}{|c|c|c|c|c|c|}
\hline \multirow{2}{*}{ No } & \multirow{2}{*}{ Tipe Kesalahan } & \multicolumn{2}{|c|}{ Frekuensi } & \multicolumn{2}{|c|}{ Presentase } \\
\hline & & $\begin{array}{c}\text { Per } \\
\text { kategori }\end{array}$ & $\begin{array}{l}\text { Per } \\
\text { Total }\end{array}$ & Per kategori & Per Total \\
\hline \multirow[t]{5}{*}{1.} & Kesalahan fonologi & & 19 & & $33,33 \%$ \\
\hline & $\begin{array}{l}\text { a. Kesalahan penggunaan huruf } \\
\text { capital }\end{array}$ & 15 & & $26,31 \%$ & \\
\hline & b. Kesalahan penulisan klitik & 2 & & $3,50 \%$ & \\
\hline & c. Kesalahan penulisan partikel & 1 & & $1,75 \%$ & \\
\hline & $\begin{array}{l}\text { d. Kesalahan penulisan } \\
\text { penggabungan kata }\end{array}$ & 1 & & $1,75 \%$ & \\
\hline \multirow[t]{5}{*}{2.} & Kesalahan morfologi & & 8 & & $14,03 \%$ \\
\hline & a. Kesalahan imbuhan ber- & 1 & & $1,75 \%$ & \\
\hline & $\begin{array}{l}\text { b. Kesalahan pemakaian sufiks- } \\
\text { nya }\end{array}$ & 1 & & $1,75 \%$ & \\
\hline & $\begin{array}{l}\text { c. Kesalahan penulisan kata } \\
\text { depan }\end{array}$ & 4 & & $7,01 \%$ & \\
\hline & d. kesalahan karena pleonasme & 2 & & $3,50 \%$ & \\
\hline \multirow[t]{7}{*}{3.} & Kesalahan sintaksis & & 30 & & $52,63 \%$ \\
\hline & a. Kalimat berstruktur tidak baku & 8 & & $14,03 \%$ & \\
\hline & b. Kalimat ambigu & 3 & & $5,26 \%$ & \\
\hline & c. Kalimat tidak jelas & 4 & & $7,01 \%$ & \\
\hline & $\begin{array}{l}\text { d. Diksi yang tidak tepat dalam } \\
\text { membentuk kalimat }\end{array}$ & 10 & & $18,51 \%$ & \\
\hline & e. Penggunaan kata mubazir & 5 & & $8,77 \%$ & \\
\hline & TOTAL & 57 & 57 & $100 \%$ & $100 \%$ \\
\hline
\end{tabular}


Berdasarkan frekuensi di atas dapat terlihat bahwa ada tiga tipe kesalahan berbahasa. Tiga tipe kesalahan tersebut meliputi pertama kesalahan fononogi terdapat 19 kesalahan atau $33,33 \%$ dari kesalahan. Kedua kesalahan morfologi terdapat 8 kesalahan atau 14,03\% dari kesalahan. Ketiga kesalahan sintaksis tersapat 30 kesalahan atau 52,63\% dari kesalahan. Frekuensi yang paling besar dari tabel frekuensi di atas adalah kesalahan sintaksis

\subsubsection{Dominan Kesalahan}

Setelah peneliti menentukan jumlah frekuensi setiap kesalahan yang dilakukan oleh siswa, peneliti membagi tipe kesalahan ke dalam tiga tipe kesalahan berbahasa. Tiga tipe kesalahan tersebut meliputi pertama kesalahan fononogi terdapat 19 kesalahan atau 33,33\% dari kesalahan. Kedua kesalahan morfologi terdapat 8 kesalahan atau 14,03\% dari kesalahan. Ketiga kesalahan sintaksis tersapat 30 kesalahan atau 52,63\% dari kesalahan. Peneliti menyimpulkan bahwa tipe kesalahan yang paling dominan adalah kesalahan sintaksis dengan total 30 kesalahan atau 52,63\%. Kesalahan tersebut terlihat pada tabel frekuensi tipe kesalahan di atas, yang baling banyak frekuensinya adalah kesalahan sintaksis. Jadi, yang paling dominan kesalahan yang dilakukan oleh siswa adalah kesalahan sintaksis.

\subsubsection{Sumber Kesalahan}

Berdasarkan gambaran kasar tentang sumber kesalahan berbahasa itu dapat dilihat bahwa sumber kesalahan berbahasa itu meliputi (1) transfer interlingual dan (2) transfer intralingual (cf. Brown, 1980). Berikut ini akan sumber kesalahan berbahasa tersebut. Tahap awal pembelajaran bahasa lazimnya ditandai oleh transfer interlingual, yakni pemindahan unsur-unsur bahasa pertama atau bahasa ibu ke dalam bahasa kedua atau bahasa yang sedang dipelajari siswa. Misalnya, murid Anda adalah seorang anak yang berbahasa ibu bahasa Jawa. Pada tahap awal pembelajaran anak itu akan tampak masuknya unsur-unsur bahasa pertamanya, yaitu bahasa Jawa ke dalam bahasa Indonesia. Artinya, ketika anak itu berbicara atau menulis dalam bahasa Indonesia, akan terdapat unsur-unsur bahasa Jawa yang digunakan dalam tuturan atau tulisannya. Misalnya, pada saat berbicara, tampak dengan jelas masuknya unsur intonasi bahasa Jawa ketika anak itu berbahasa Indonesia. Bahkan mungkin juga tampak jelas masuknya unsur tata bentuk, tata kalimat, bahkan unsur leksikal bahasa pertama ke dalam bahasa Indonesia. Berikut data yang ditemukan dalam karangan siswa cerita fabel yang menunjukkan kesalahan interlingual dan intralingual.

a) Transfer interlingual.

1. Ayam lainnya pun tidak mau mengalah dan malahan saling berantem dengan jalunya.

2. Ayam betina yang mengengkrami sudah meninggal waktu kamu kecil.

Kata malahan dan mengengkrami adalah kosakata bahasa Jawa yang ditransfer ke dalam bahasa Indonesia. Anak mengalami kesulitan untuk menyebutkan kata itu dalam bahasa Indonesia karena dalam bahasa Indonesia padanan yang cocok untuk kata itu tidak ada. Bentuk lazim kata malahan dan mengengkrami harus dikatakan sebagai semestinya dan mengerami. Terdapat perbedaan antara kosakata bahasa Indonesia dengan kosakata bahasa Jawa tersebut, siswa cenderung memindahkan begitu saja kosakata bahasa Jawa itu ke dalam tuturan bahasa Indonesianya. Muncul juga kata malahan dan mengengkrami dalam bahasa Indonesia. Kata mengengkrami berasal dari bahasa Jawa angkrem. 
a) Transfer Intralingual

Sumber kesalahan berbahasa dapat dilacak dari sistem bahasa kedua yang dipelajari oleh siswa. Jika siswa itu belajar bahasa Indonesia, sumber kesalahan berbahasanya dapat dilacak dari sistem atau kaidah dalam bahasa Indonesia itu sendiri. Kaidah itu dapat meliputi kaidah tata bunyi, tata bentuk, tata kalimat, kaidah leksikal, bahkan kaidah semantik. Berdasarkan hasil penelitian, tampak bahwa sumber kesalahan ini merupakan sumber kesalahan terbesar. Bahasa pertama atau bahasa ibu yang sering dituduh sebagai sumber kesalahan terbesar berbahasa kedua itu ternyata hanya menjadi faktor penyebab yang kecil saja, yakni kira-kira 13 persen, sedangkan selebihnya adalah sumber dari sistem bahasa kedua itu sendiri (Dulay, 1982).

Kesalahan-kesalahan yang sering terjadi karena transfer intralingual itu di antaranya sebagai berikut.

1) Penghilangan partikel

Kesalahan penulisan partikel - pun kebanyakan terjadi karena penulis merangkai partikel yang seharusnya ditulis terpisah. Kesalahan kalimat (1) menunjukkan penggunaan partikel -pun yang penulisannya dirangkai. Bentuk penulisan yang benar ditunjukkan kalimat (1a) yang sesuai kaidah penggunaan partikel -pun penulisannya terpisah dengan kata yang mendahuluinya. Berikut data yang menunjukkan kesalahan penggunaan partikel.

(1) Diapun menang bersama.

(1a) Dia pun menang bersama.

2) Penggunaan gaya bahasa tautology

Penggunaan gaya bahasa tautologi yakni penggunaan kata yang sama atau mirip maknanya secara bersamaan.

(1) Saat itu secara kebetulan mereka secara bersamaan masing-masing tiba di tepi jurang yang dibawahnya mengalir air sungai yang sangat deras. (bentuk salah)

Selayaknya siswa memilih satu bentuk untuk tiap-tiap kalimat. Kalimat tersebut akan menjadi benar apabila dibenahi menjadi kalimat (1a) di bawah ini.

(1a) Saat itu mereka secara kebetulan bersamaan tiba di tepi jurang dan di bawahnya mengalir air yang sangat deras. (bentuk benar)

3) Penggunaan gaya bahasa pleonasme

(1) Elang itu kini terbang melayang di atas.(bentuk salah)

(1a) Elang itu kini terbang melayang. (bentuk benar)

Bentuk kesalahan kalimat (1) merupakan kesalahan bentuk pada frase melayang di atas. Penggunan frasa tersebut menjadi berlebihan karena kata melayang digabung dengan di atas yang sebenarnya memiliki arti yang sama karena melayang pasti ke atas. Pembetulan kalimat (1a) merupakan bebtuk efektif dari kalimat (1) dengan menghilangkan kata di atas.

(2) Si kelinci apalagi sangat lebih marah kepada kucing. (bentuk salah)

(2a) Si kelinci apalagi lebih marah kepada kucing. (bentuk benar)

Bentuk kesalahan kalimat (2) merupakan bentuk kesalahan karena bentuk superlatif. Bentuk superlatif yang berlebihan terdapat pada frasa sangat lebih marah. Kalimat (2a) menunjukkan kalimat benar cukup menggunakan frasa lebih marah. Penghilangan kata sangat pada kalimat (2) bertujuan untuk menghemat kalimat. 
4) Kesalahan Menyusun Bentuk dalam Sebuah Konstruksi

Kesalahan menyusun bentuk dalam sebuah kontruksi kalimat (1) di bawah ini salah. Penyebab kesalahan konstruksi adalah penggunaan konjungsi dan pada awal kalimat yang menyebabkan penghilangan subjek. Konjungsi dan seharusnya diletakkan ditengah kalimat sebagai penghubung antar kalimat.

(1) Dan akhirnya dia sudah tau penyebabnya adalah seekor burung beo itu dan dia menghukum burung beo. (bentuk salah)

(1a) Akhirnya dia sudah tahu penyebabnya karena seekor burung beo dan dia menghukum burung beo. (bentuk benar)

Bentuk pembetulan pada kalimat (1a) menunjukkan kontruksi kalimat yang tepat. Penghilangan konjungsi dan akan menunjukkan kedudukan fungsi subjek pada kalimat.

\section{Simpulan}

Berdasarkan analisis kesalahan berbahasa pada penulisan cerita fabel siswa kelas VIII E SMP Muhammadiyah 2 Surakarta dapat disimpulkan bahwa kesalahan berbahasa yang dilakukan oleh siswa kelas VIII E SMP Muhammadiyah 2 Surakarta dalam pembuatan karangan cerita fabel terdapat 57 kesalahan. Kesalahan tersebut terbagi menjadi tiga tipe kesalahan. Kesalahan berbahasa tersebut meliputi kesalahan bidang fonologi 33,33\%, kesalahan bidang morfologi 14,03\%, dan kesalahan bidang sintaksis 52,63\%. Tipe kesalahan yang paling dominan adalah kesalahan sintaksis terdapat 30 kesalahan atau 52,63\% dari kesalahan. Peneliti juga menemukan 2 dominan sumber kesalahan berbahasa yaitu transfer interlingual dan transfer intralingual.

\section{Daftar Pustaka}

Fauziati, Endang. (2009). Readings On Applied Linguistics: A Handbook for Language Teacher and Teacher Researcher.Surakarta: Era Pustaka

Markhamah; Atiqa Sabardila. (2011).Analisis Kesalahan \& Karekteristik Bentuk Pasif. Solo:Jagat Abjad.

Tarigan, Henri Guntur.(1990). Pengajaran Analisis Kesalahan Berbahasa. Bandung: Angkasa

Sudaryanto. (1993). Metode dan Aneka Teknik Analisis Bahasa. Yogyakarta:Duta Wacana University Perss 